TIPA. Travaux interdisciplinaires sur la parole et le langage

$27 \mid 2008$

Apprentissage et acquisition d'une langue seconde

\title{
Intonation et mélismes dans le discours oral spontané en basaa
}

Thèse dirigée par Geneviève Caelen-Haumont, soutenue le 4 novembre 2008

Emmanuel-Moselly Makasso

\section{(2) OpenEdition}

Journals

Édition électronique

URL : https://journals.openedition.org/tipa/394

DOI : 10.4000/tipa.394

ISSN : 2264-7082

Éditeur

Laboratoire Parole et Langage

Édition imprimée

Date de publication : 1 juin 2008

ISSN : 1621-0360

Référence électronique

Emmanuel-Moselly Makasso, « Intonation et mélismes dans le discours oral spontané en basaa »,

TIPA. Travaux interdisciplinaires sur la parole et le langage [En ligne], 27 | 2008, mis en ligne le 04

décembre 2012, consulté le 08 septembre 2021. URL : http://journals.openedition.org/tipa/394 ; DOI : https://doi.org/10.4000/tipa.394

Ce document a été généré automatiquement le 8 septembre 2021.

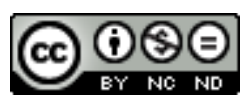

La revue TIPA. Travaux interdisciplinaires sur la parole et le langage est mise à disposition selon les termes de la licence Creative Commons Attribution - Pas d'Utilisation Commerciale - Pas de Modification 4.0 International. 


\title{
Intonation et mélismes dans le discours oral spontané en basaa
}

Thèse dirigée par Geneviève Caelen-Haumont, soutenue le 4 novembre 2008

\author{
Emmanuel-Moselly Makasso
}

1 Ce travail qui se consacre à la prosodie du bàsàa, une langue bantoue à tons parlée au Cameroun, souscrit à une longue tradition d'analyse prosodique développée depuis plusieurs années au Laboratoire Parole et Langage : Prosodie, formes et fonctions.

2 Les phénomènes prosodiques envisagés au premier plan sont l'intonation et le mélisme. Cette dernière notion, d'inspiration musicale et adaptée en linguistique par CaelenHaumont et Bel (2000), renvoie à une vaste excursion de la courbe mélodique au cours de l'articulation d'un mot ou d'un groupe de mots. Cette notion se manifeste sur le plan prosodique par une proéminence lexicale dont les auteurs attribuent l'origine à l'expression de la subjectivité des locuteurs. Après une application du concept de mélisme au français et à l'anglais, l'adaptation du concept en bàsàa nous montre une juxtaposition du mélisme sur les autres phénomènes prosodiques de la langue, dont le ton et l'intonation.

3 À partir d'un corpus d'interviews radiophoniques de 6 locuteurs (une femme et 5 hommes), nous avons appliqué le modèle MomeL-Melism, un script sous Praat (Boersma \& Weenick). Cet outil qui permet la segmentation de la voix humaine en neuf niveaux : aigu, supérieur, haut, élevé, moyen, bas, inférieur et grave) détermine la proéminence lexicale car les mélismes sont concernés par les trois premières catégories, les plus hautes.

4 Après une description linguistique et prosodique de la langue bàsàa, nous avons procédé à une double analyse des mélismes issus de notre corpus: une analyse phonologique et une interprétation linguistique et pragmatique. La description phonologique se consacre à la réalisation tonale, une syllabe tonale étant entendue ici comme une séquence de deux cibles tonales déterminées automatiquement par le modèle. De même, cette description s'est focalisée sur la pente mélodique, sur les types 
de structures et le constat est que les mélismes ne sont pas liés par des contraintes linguistiques.

5 Cette thèse s'est ensuite intéressée à l'interprétation de la proéminence prosodique, sur quatre dimensions : la subjectivité linguistique, la structure du discours, la structure informationnelle et l'analyse sémantique et pragmatique des réseaux lexicaux autour des mélismes lexicaux.

6 En somme, quelle que soit la dimension d'étude du mélisme (subjectivité lexicale, focus, deixis-anaphore, etc.), celui-ci n'a pas de zone d'apparition prédéterminée dans l'énoncé. Il apparaît au gré de l'expression de l'affectivité par le locuteur.

7 This work, grounded on the prosody of Bàsàa, a tone Bantu language spoken in Cameroon, draws on a long tradition of the Form-Functions of prosody developed in the Laboratoire Parole et Langage, in Aix-en-Provence.

The prosodic phenomenon in question here are Intonation and melism. The latter is a word borrowed from the domain of singing and proposed in linguistics by CaelenHaumont and Bel (2000). It stands for a large melodic excursion over the course of a whole word or a string of words. This notion was successfully applied in French and English. Adapted to Bàsàa language, melisms are higher in pitch than the normal register of high tones. Moreover, melism is a macrolinguistic phenomenon that is superimposed to other prosodic phenomena like tone and intonation.

From a corpus of spoken radio interviews of 6 bàsàa speakers ( 1 female and 5 males), we applied the Momel-Melism tool, a script running under the Praat software (Boersma \& Weenick). This specific tool provided us with a segmentation of human voice into 9 levels, Acute, Superior, High, Elevated, Mean, Central, Low, Inferior, Grave. Melisms are concerned only with the first three ones, which are the highest. The melisms gathered from this corpus were treated in two ways: first a phonological description and then a semantic and pragmatic description.

The phonological description consisted of bringing out the tonal correlates, provided the Momel model sorts out tonal syllables, understood as sequences of two tonal targets, automatically fixed by the script, which are different from lexical ones. Likewise, the phonological description focused on the direction of the melodic slope, and the types of melism structures in phrases. An outcome of this analysis is that it appears that melisms are not constrained by any phonological, syntactic or semantic phenomenon. Following that description, the second part of the work was concerned with the interpretation of melodic prominence on words. Four dimensions are considered here: the way melisms mark linguistic subjectivity, the way grammatical melisms act in discourse structure, by marking coherence relations, the way melisms act in information structure and finally a semantic and pragmatic interpretation of lexical networks around lexical melisms.

11 In conclusion, melisms can appear anywhere in the utterance, regardless of the linguistic perspective adopted: lexically subjective or not, focus or not, deictic or anaphoric, etc. The real conditioning factor for the appearance of melisms seems to be the expressiveness of the speaker. 